HRONIKA - CHRONICLE

\title{
Seminārs Latviešu raksti un raksti Latvijā 16.-19. gadsimtā — pētniecības aktualitātes un problēmas, 2019. gada 11. janvārī
}

2019. gada 11. janvārī Latvijas Universitātes Humanitāro zinātņu fakultātē notika devītais starptautiskais seminārs „Latviešu raksti un raksti Latvijā 16.-19. gadsimtā - pētniecības aktualitātes un problēmas“. Starpdisciplinārajā seminārā piedalījās valodnieki, kas stāstīja par saviem jaunākajiem atradumiem un pētījumiem. Šoreiz seminārā tika nolasīti septiņi referāti. Ar laba vēlējumiem semināru atklāja LU HZF dekāne prof. Ilze Rūmniece.

Sarīkojuma pirmās dal̦as referāti bija veltīti 16. un 17. gadsimta latviešu rakstu problemātikai. Anta Trumpa (LU Latviešu valodas institūts) referātā „Blēži un liekuḷi latviešu valodas senajos tekstos: nozīmes pārmaiņa?“ pievērsās vārdu blèdis, blèdīgs un blèdnieks lietojumam 17. gadsimta latviešu valodas tekstos. Referāta autore secināja, ka šo vārdu lietojums senajos tekstos salīdzinājumā ar mūsdienām ir bijis plašāks, vārdi ir attiecināti ne tikai uz viltniekiem un škselmijiem, bet arī uz laundariem, neliešiem un zaimotājiem. Savukārt vārds blèdnieks ar nozīmi 'liekulis' ir lietots tikai 17. gadsimta beigās un jo īpaši Bībeles tulkojumā, šādu lietojumu neapstiprina ne agrākie, ne arī vēlākie leksikogrāfiskie avoti.

Par „Reduplikāciju Georga Mancel̦a sprediksos“ runāja Anna Frīdenberga (LU Latviešu valodas institūts). Viņa aplūkoja dažādas reduplikācijas izpausmes Georga Manceḷa Spredik̦u grāmatā jeb Lang-gewünschte Lettische Postill (1654). Reduplikāciju, kas izpaužas kā saknes, celma vai visa vārda atkārtošana, latviešu valodā izmanto pastiprinājuma izteikšanai. G. Manceḷa sprediksi balstās uz reliǵiskās retorikas paņēmieniem, tiem raksturīga tēlaina valoda, kupla un daudzkrāsaina izteiksme, kā arī dažādu stilistisko līdzekḷu, tai skaitā reduplikācijas, izmantojums. Substantīvu pastiprināšanai G. Mancelis visbiežāk lietojis t. s. pastiprinājuma ğenitīvu, sastopami tādi vārdu savienojumi

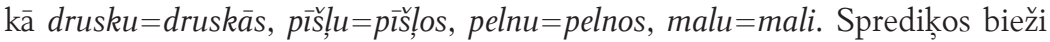
lietoti arī adverbiālie vārdu savienojumi kārt=kārtim, tieš=tiešam, pār = pārim. Tomēr visbiežāk tiek pastiprināti verbi - gan ar tās pašas saknes substantīvu vai adverbu, gan ar divdabi vai nenoteiksmi. G. Mancelim l̦ loti raksturīgi reduplikatīvie savienojumi ar adverbiem -in un -tin, piemēram, audzin aug, lūstin lūst, šādi teicieni ļoti bieži sastopami arī tautasdziesmās. Domājams, ka šis modelis ticis aktīvi lietots tautas valodā un G. Mancelis to ir ievērojis un izmantojis. L̇oti bieži sastopami arī vārdu savienojumi, kur verbu pastiprina substantīvs ar -šana, turklāt G. Mancelis šādos gadījumos lietojis arī apzīmētāju liels: lielu 
krākšanu krāc, lielu tvīkšanu tvīkst. Reduplikācijas plašais izmantojums sprediķos saistāms gan ar latviešu folkloras, gan ar sarunvalodas ietekmi.

Vilı̧nas Universitātes pārstāve Ernesta Kazakēnaite (Ernesta Kazakènaitè), kas jau pēc semināra (22. februārī Viḷı̧āa) aizstāvēja savu promocijas darbu, runāja par tekstuālajām sakritībām Lūkas evaņgéelija tekstos no pirmajām perikopēm līdz E. Glika Bībeles tulkojumam. Kaut pirmo reizi pilnīgs Lūkas evanggēelijs latviešu valodā izdots 1685. g., tomēr tas netapa tukšā vietā-izvilkumi zināmi jau kopš 16. gs. Strukturāli salīdzinot zināmās iespiestās perikopes ar Glika Lūkas evaņgêeliju, redzams, ka tā ir aptuveni trešā dą̧a no visa evaņgēelija teksta. Referātā uzmanība tika pievērsta Glika Jaunās Derības un perikopju krājumos esošo izvilkumu tekstuālajām sakritībām. Runātāja secināja, ka Gliks gandrīz pilnīgi sekojis Fīrekera tulkojumam, kas ievietots 1685. gada Vermehretes Lettisches Handbuch, tomēr no 347 kopīgajiem pantiem tikai 127 sakrīt vārds vārdā, bet 76-arī forma formā. Gliku abu izdevumu kopīgajiem pantiem varētu uzskatìt nevis par tulkotāju, bet par redaktoru, jo visi 29 izvilkumi ir tikuši laboti. Iemesli ir dažādi, bet lielākoties labots, balstoties uz oriǵinālavotiem. Tāpat vērojama arī Glika tieksme izvairīties no K. Fīrekera piedāvātajiem paralēlajiem variantiem, kas Kurzemes rokasgrāmatā rakstīti iekavās.

Glika Bībeles tulkojumam un citiem 17. gs. tekstiem pievērsās arī LU doktorante Jolanta Višñoha (Jolanta Wiśnioch). Viņas pētījuma uzmanības lokā ir darbības vārdu formu lietojums šajos avotos. Analīzē konstatēts, ka G. Manceļa perikopju materiāls izdevumos starp 1631. un 1655. gadu veido veselumu ar šādām pazīmēm: 1) galotne -eeta indikatīva un imperatīva dsk. 2. pers. formās; 2) darbības vārda būt pagātnes 3. pers. izmantota vienīgi forma by;3) primāro darbības vārdu pagātnes 3. pers. galotnē izmantota gandrīz vienīgi galotne $-e$.

Glika un Fīrekera perikopēs situācija ir atšksirīga: 1) Par gandrīz vienīgo indikatīva galotni dsk. 2. pers. formās kalpo galotne -at/-aht. Glika Bībeles Mateja un Marka evangêeelijos šajā funkcijā izmantota galvenokārt galotne -aht, bet Jāņa evaņgéēijā -at. Lūkas evangêeelija tekstā abu rakstības variantu skaits ir identisks $-53 / 53$. Fìrekera perikopēs lietota gandrīz vienīgi galotne -aht (1685. g. gramatikā Erster Versuch - -at). Par pavēles izteiksmes rādītāju Fīrekera un Glika perikopēs kalpo gandrīz vienīgi galotnes -eet, kā arī -ait $\bar{a}$-celma verbiem.

2) Fīrekera un Glika perikopju tulkojumā verba būt pagātnes 3. pers. forma parādās divos variantos: pilnajā bija un ar apokopētu galotni - bij. Turklāt, īpaši Glika Bībelē, abu galotņu lietojums variē dažādās grāmatās. Mt un Mk tekstos abu formu skaits nedaudz svārstās par labu garākajai formai. Forma bija abos tekstos izmantota pārsvarā patstāvīga darbības vārda funkcijā. Abos tekstos palīgverba funkcijā lietota galvenokārt saīsināta forma bij. Lk un Jñ evaņgéliju tekstos situācija ir atšksirīga. Verba pilnas formas ir daudz biežākas par formām ar apokopi ( Lk - 158 un 70, Iṇ - 115 un 77), tomēr Lk un Iņ 
evaņgéelijos garās formas nozīmes specializācijas process nav tik izteikts. Līdzịga situācija vērojama arī Fīrekera perikopju materiālā. Salīdzinot abu avotu materiālu, skaidri redzams, ka Gliks vairākos gadījumos ir mainīipis Fīrekera perikopēs lietotās formas.

3) Verbu pagātnes formu lietojums analizētajās Glika un Fīrekera perikopēs ir svārstīgs. Mk un Mt tekstos lietota Manceḷa darbos izmantotā sistēma, turpretim Lk un Jñ tekstos blakus pagātnes $\bar{e}$-celma galotnei $-e$ primāro tiešo verbu formās biežāk parādās $\bar{a}$-celma galotne $-a$. Lk un Jṇ reǵistrētās galotnes dạ̄ẹi pārklājas ar vēsturisko pagātnes celmu dalījumu. Fīrekera perikopju tulkojumā lietotās primāro darbības vārdu 3. pers. formas uzrāda paralēles ar Lk un Jņ materiālu.

Šì pètījuma rezultāti atbalsta E. Kazakēnaites secinājumus par to, ka Glika Bībeles tekstā visas evaņgéeliju perikopes ir tikušas pārņemtas no Fīrekera tulkojuma, tomēr neviena no tām nesakrīt ar Fīrekera tekstu pilnībā. Redzams, ka Gliks, pārṇemot Fīrekera materiālu, ir veicis zināmus labojumus, kas parāda Glika tieksmi sistematizēt un sakārtot verbu formu rakstību.

Semināra otrā dạ̧a pēc pārtraukuma bija veltīta 19. un arī 20. gadsimta procesiem latviešu valodas vēsturē. Pēteris Vanags (LU / Stokholmas Universitāte) savā referātā „Latviešu draugu biedrības devums latviešu rakstu valodas normēšanā" pievērsās vācbaltu mācītāju latviešu valodas normēšanas un kopšanas darbam 19. gs. pirmajā pusē. Tas pamatā tika izvērsts ar LDB izdevuma Magazin, kā arī citu publikāciju palīdzību. Lai gan sākotnēji biedrības locekḷiem bija plāni gan reformēt latviešu rakstību, gan kopt citus valodas līmeņus, ne visus darbus izdevās novest līdz kādam taustāmam rezultātam. Turklāt jau ar gadsimta vidu latvieši paši pārṇēma valodas tālākveidošanu savās rokās. Jautājums paliek, vai LDB un tās biedru darbība ir atstājusi ietekmi latviešu rakstu valodas attīstībā. No vienas puses, varētu uzskatīt, ka biedrības darbībai tiešas ietekmes nebija, jo latviešu rakstība 19. gs. vidū kopumā palika tāda pati, kāda tā bija 19. gs. sākumā. Arī rakstu valodas gramatika un vārdu krājums vēl 19. gs. vidū bija spēcīgā vācu valodas iespaidā. No otras puses, nevar noliegt, ka LDB sanāksmēs un izdevumā Magazin noritējusī plašă domu apmaiņa gan par ortogrāfijas, gan citām problēmām, arī vērtīgie materiālu krājumi bija nozīmīgs pamats, uz kā varēja turpināties diskusijas 19. gs. otrajā pusē jau Rīgas Latviešu biedrības paspārnē. Arī LDB un tās locekḷu publikācijas latviešu valodā un tajās izmantotā leksika bija viens no pamatiem, uz kā veidojās jaunlatviešu rakstu valoda un tālāk arī mūsdienu valoda.

LU Latviešu valodas institūta direktore Ilga Jansone savā referātā ,,Turnas ezeru grupa: pārsteigumi un mīklas“ analizēja Ērǵemes pagasta Turnā esošās ezeru grupas - Valdis, Kukris, Vircelis, Rūksa ezers u. c. - nosaukumus dažādos 19. -21. gs. avotos. Pētījums rāda, ka šo ezeru nosaukumiem piemīt visai strauja mainība, kas saistīta ar dažādiem procesiem gan dabā, gan sociālajā vēsturē. 
Aplūkoto limnonīmu etimolog̣iskā analīze liecina par spēcīgu igauņu valodas iespaidu, kas nav pārsteigums, jo ezeru grupa atrodas tuvu latviešu un igauņu etniskajai robežai, kas laika gaitā arī ir bijusi mainīga.

Dzintra Paegle (Rīga) referātā „Suntažu mācītāja Emīla Lopenoves (1820-1897) 1859. gada sprediķis“" analizēja Latvijas Valsts vēstures arhīva materiālos (233. fonds, 3. apraksts, 3017. lieta 166.,167. lp.) atrasto E. Lopenoves sprediķi. Tas rakstīts ar paša mācītāja roku latviešu valodā. Sprediķa saturs atstāj nomācošu iespaidu, bet ortogrāfiski tas atbilst 19. gs. rakstu tradīcijai, vienīgi garie patskaņi un divskanis /uo/ rakstīts ar taisnu gulošu svìtru virs burta: $\langle\overline{\mathrm{a}}>,<\overline{\mathrm{e}}>,<\overline{\mathrm{i}}>,<\overline{\mathrm{u}}>,<\overline{\mathrm{o}}>$. Tas liecina, ka autors kā LDB biedrs ir sekojis diskusijai par latviešu valodas ortogrāfijas uzlabošanu, turklāt mēǵinājis kādus ieteikumus arī praktiski lietot. E. Lopenoves latviešu valoda ir bagāta, sprediķa teksts rūpīgi izstrādāts, tajā saskatāmas dzimtās vācu valodas pēdas, atspulgi no dažām latviešu izloksnēm (fchmuidris kōks, pee tewi, pee mani), periodikas (prātu mōdināt, bārgs) un reliğiskās literatūras (wells, purrs) tradīcijām.

Seminārā piedalìiās ap divdesmit runātāju un klausìtāju. Kā vienmēr klāt bija arī profesors Trevors G. Fennels (Trevor G. Fennell, Flindersa Universitāte, Adelaide, Austrālija). Dalībnieki bija priecīgi par iespēju apmainīties domām un vienojās satikties arī desmitajā seminārā nākamgad.

\author{
Pēteris Vanags \\ Latvijas Universitātes \\ Humanitāro zinātņu fakultāte \\ Baltu valodniecības katedra \\ Visvalža iela 4a, LV-1050 Rīga, Latvija \\ pvanags@latnet.lv
}

